\title{
Model for Predictive Analysis of the Concentration of Phosphorus Removed during Leaching of Iron Oxide Ore in Sulphuric Acid Solution
}

\author{
C. I. Nwoye ${ }^{*^{1}}$ and S. Ndlu ${ }^{2}$ \\ 1. Department of Materials and Metallurgical Engineering Federal University of \\ Technology, Owerri, Imo State. \\ 2. School of Process \& Materials Engineering, University of the Witwatersrand, \\ Johannesburg, South Africa. \\ *Corresponding Author: chikeyn@yahoo.com
}

\begin{abstract}
Model for predictive analysis of the concentration of phosphorus removed (relative to the initial and final pH of the leaching solution) during leaching of iron oxide ore in sulphuric acid solution has been derived. It was observed that the validity of the model is rooted in the mathematical expression; $(P / N)^{1 / 3}=\left(e^{\gamma / \alpha}\right)$ where both sides of the relationship are almost equal. The model; $P=4.25\left(e^{\gamma / \alpha}\right)^{3}$ shows that the concentration of phosphorus removed is dependent on the values of the initial and final $\mathrm{pH}$ of the leaching solution. In all, the positive or negative deviation of the model-predicted phosphorus concentration from its corresponding value obtained from the experiment was found to be less than 29\%, which is quite within the acceptable deviation limit of experimental results hence establishing the validity and precision of the model in its application for predicting quantitatively the concentration of phosphorus removed during the leaching process.
\end{abstract}

Key Words: Model, Prediction, Phosphorus Removed, Sulphuric Acid, Iron Oxide Ore, Leaching. 


\section{INTRODUCTION}

Lee et al. [1] reported that the leaching of $3 \mathrm{~g} / \mathrm{L}$ pure haematite $(98.2 \%$ purity, $105-140 \mu \mathrm{m}$ size range) using $0.048-0.48 \mathrm{M}$ oxalic acid at $80-100^{\circ} \mathrm{C}$ passed through a maximum peak at $\mathrm{pH} 2.5$.

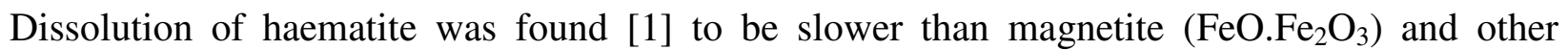
hydrated iron oxide such as goethite $(\alpha-\mathrm{FeOOH})$, lapidochrosite $(\gamma-\mathrm{FeOOH})$ and iron hydroxide $\left(\mathrm{Fe}(\mathrm{OH})_{3}\right)$.

The dissolution of iron oxide is believed to take place via a photo-electro chemical reduction process, involving a complicated mechanism of charge transfer between the predominant oxalate species, namely ferric oxalate $\mathrm{Fe}\left(\mathrm{C}_{2} \mathrm{O}_{4}\right)_{3}{ }^{3-}$, ferrous oxalate $\mathrm{Fe}\left(\mathrm{C}_{2} \mathrm{O}_{4}\right)_{2}{ }^{2-}$ acting also as an auto catalyst, and the oxalate ligand on the iron oxide surface [2].

The dissolution of iron oxides in oxalic acid was found to be very slow at temperatures within the range $25-60^{\circ} \mathrm{C}$, but its rate increases rapidly above $90^{\circ} \mathrm{C}$ [3]. The dissolution rate also increases with increasing oxalate concentration at the constant $\mathrm{pH}$ values set within the optimum range of $\mathrm{pH}$ 2.5-3.0. At this optimum $\mathrm{pH}$, the dissolution of fine pure haematite $\left(\mathrm{Fe}_{2} \mathrm{O}_{3}\right)$ (105$140 \mu \mathrm{m})$ follows a diffusion-controlled shrinking core model [3].

Taxiarchour et al [4] reported that it took close to $40 \mathrm{~h}$ to dissolve $80 \%$ of pure haematite slurry ( $97 \%$ purity, $0.022 \% \mathrm{w} / \mathrm{v}$ or $0.21 \% \mathrm{~g} / \mathrm{L} \mathrm{Fe}_{2} \mathrm{O}_{3}$ ) at $\mathrm{pH} 1$. He stated that even at $90^{\circ} \mathrm{C}$, it required close to $10 \mathrm{~h}$ to achieve $95 \%$ dissolution of iron of the slurry at $\mathrm{pH} 1$. They also dissolved iron using $0.1-0.5 \mathrm{M}$ oxalic acid (pH1-5) to dissolve iron from a $20 \% \mathrm{w} / \mathrm{v}$ slurry ( $83 \%$ of particle size in the range $0.18-0.35 \mathrm{~mm}$, containing $0.029 \% \mathrm{Fe}_{2} \mathrm{O}_{3}$ ). The iron oxide concentration in the leach is equivalent to $0.058 \mathrm{~g} / \mathrm{L} \mathrm{Fe}_{2} \mathrm{O}_{3}$.

The speciation of $\mathrm{Fe}(\mathrm{III})$ oxalate and $\mathrm{Fe}(\mathrm{II})$ oxalate has been found [5] to be governed by $\mathrm{pH}$ and total oxalate concentration. For a having $\mathrm{pH}>2.5$ and an oxalate concentration higher than $0.1 \mathrm{M}$, the most predominant $\mathrm{Fe}(\mathrm{III})$ complex ion existing is $\mathrm{Fe}\left(\mathrm{C}_{2} \mathrm{O}_{4}\right)^{3-}{ }_{3}$. At these conditions, $(\mathrm{pH}>2.5$ and an oxalate concentration higher than $0.1 \mathrm{M}$ ) the predominant $\mathrm{Fe}$ (II) complex species is $\mathrm{Fe}\left(\mathrm{C}_{2} \mathrm{O}_{4}\right)^{2-}{ }_{2}$. 
Nwoye [6] derived a model for quantitative analysis of dissolved iron in oxalic acid solution in relation to the final $\mathrm{pH}$ of the solution during leaching of iron oxide ore;

$$
\gamma=0.5\left(\frac{\mathrm{K}_{1}\left[\% \mathrm{Fe}_{2} \mathrm{O}_{3}\right]+\mathrm{K}_{2}[\% \mathrm{Fe}]}{[\% \mathrm{Fe}]\left[\% \mathrm{Fe}_{2} \mathrm{O}_{3}\right]}\right)
$$

Where

$\mathrm{K}_{1}$ and $\mathrm{K}_{2}=$ Dissolution constants of $\mathrm{Fe}$ and $\mathrm{Fe}_{2} \mathrm{O}_{3}$, respectively.

$\gamma=\mathrm{pH}$ of leaching solution after time $\mathrm{t}$ (mins.).

The values of the dissolution constants compared with those of $\% \mathrm{Fe}$ and $\% \mathrm{Fe}_{2} \mathrm{O}_{3}$ from the experiment [6] indicate clearly that the constants $K_{1}$ and $K_{2}$ are numerical equivalence of the chemical resistance to the dissolution of $\mathrm{Fe}$ and $\mathrm{Fe}_{2} \mathrm{O}_{3}$ (respectively) in oxalic acid solution. It was found that $\mathrm{K}_{1} \approx 2 \mathrm{~K}_{2}$ indicating twice chemical resistance to the dissolution Fe compare to that of $\mathrm{Fe}_{2} \mathrm{O}_{3}$. This expression agreed with the higher percentage of $\mathrm{Fe}_{2} \mathrm{O}_{3}$ dissolved compared to that of the corresponding Fe.The model also predicted the final $\mathrm{pH}$ of the leaching solution when the concentrations of $\mathrm{Fe}$ and $\mathrm{Fe}_{2} \mathrm{O}_{3}$ dissolved (at a temperature of $30^{\circ} \mathrm{C}$ and average ore grain size; $150 \mu \mathrm{m})$ are known.

Nwoye et al [7] derived a model for predicting the concentration of dissolved iron during leaching of iron oxide ore in sulphuric acid solution. The model is stated as;

$$
\% \mathrm{Fe}=0.35(\alpha / \mathrm{T})^{3}
$$

Where

$\mathrm{T}=$ Solution temperature at the time $\mathrm{t}$, when the concentration of dissolved iron is evaluated. $\left({ }^{0} \mathrm{C}\right)$

$0.35=(\mathrm{pH}$ coefficient for iron dissolution in sulphuric acid solution during the leaching process) determined in the experiment [7].

$\alpha=$ Final $\mathrm{pH}$ of the leaching solution at the time $\mathrm{t}$, when the concentration of dissolved iron is evaluated.

The model (formulated at conditions; leaching temperature of $25^{\circ} \mathrm{C}$, initial solution $\mathrm{pH} 5.0$ and average grain size; $150 \mu \mathrm{m}$ ) is dependent of the final $\mathrm{pH}$ and temperature of the leaching solution. The model shows that the concentration of iron dissolved during the leaching process is directly proportional to the third power of the ratio of final leaching and temperature. 
It has been found $[8,9]$ that the final $\mathrm{pH}$ of the leaching solution depend on the leaching time, initial $\mathrm{pH}$ for the leaching solution and the leaching temperature. Past reports [10-15] have been expounded researches carried out to remove phosphorus from steel during steel making. Findings from all these works carried out, pointed out high oxygen activity and low treatment temperature as the only essential and unavoidable process conditions which can enhance the rate of dephosphorization.

Removal of phosphorus from iron has been reportedly achieved only by oxidation during steel making, under the influence of a basic slag which is principally made up of $\mathrm{CaO}$ [16]. Model has been derived [17] for predicting the concentration of phosphorus removed during leaching of iron oxide ore in oxalic acid solution. The model is expressed as;

$$
\mathrm{P}=\left(\frac{150.5}{\mu \alpha}\right)
$$

Where

$\mathrm{P}=$ Concentration of phosphorus removed during the leaching process $(\mathrm{mg} / \mathrm{Kg})$

$(\mu)=$ Weight input of iron oxide ore $(\mathrm{g})$

$(\alpha)=$ Final $\mathrm{pH}$ of the leaching solution at the time $\mathrm{t}$ when $\mathrm{P}$ is evaluated

$150.5=(\mathrm{pH}$ coefficient for phosphorus dissolution in oxalic acid solution during the process) determined in the experiment [17].

The model [17] predicted the concentration of phosphorus removed, with high degree of precision being dependent on the final $\mathrm{pH}$ of the leaching solution and weight input of the iron oxide ore. It also shows that the concentration of phosphorus removed (at a temperature of $25^{\circ} \mathrm{C}$, average ore grain size; $150 \mu \mathrm{m}$ and initial leaching solution $\mathrm{pH} 5.5$ ) is inversely proportional to the product of the final $\mathrm{pH}$ of the leaching solution and the weight input of the iron oxide ore.

It has been reported [18] that phosphorus could be removed from Itakpe iron oxide ore through a leaching process using sulphuric acid solution. Chemical analysis carried out on the iron ore indicates that the percentage of phosphorus in the ore is about $1.18 \%$, which from all indication is quite high and could cause embrittlement and other adverse effects on the service life of engineering materials made from such iron ore. This was the basis for the dephosphorization 
process carried out [18]. Phosphorus was removed (at a temperature of $25^{\circ} \mathrm{C}$, average ore grain size; $150 \mu \mathrm{m}$ and initial leaching solution $\mathrm{pH}$ range $0.47-0.53$ ) and then dissolved in the acid solution in the form of phosphorus oxide.

The aim of this work is to derive a model for predictive analysis of the concentration of phosphorus removed relative to the initial and final $\mathrm{pH}$ of the solution during leaching of Itakpe (Nigeria) iron oxide ore using sulphuric acid solution. This derivation is embarked on in furtherance of the previous work [18].

\section{MODEL}

The ore is assumed to be stationary in the reaction vessel during the leaching process and contains the un-leached iron as part of reaction remnants. The ore is attacked by hydrogen ions from sulphuric acid within the liquid phase, and in the presence of oxygen.

\subsection{Model Formulation}

Results from experimental work [18] carried out at SynchroWell Research Laboratory, Enugu were used for the model derivation. These results are as presented in Table 1.

Computational analysis of these experimental results [18] shown in Table 1, resulted to Table 2 which indicate that;

$$
\begin{aligned}
& (\mathrm{P} / \mathrm{N})^{1 / 3}=\left(\mathrm{e}^{\gamma / \alpha}\right) \quad \text { (approximately) } \\
& \mathrm{P} / \mathrm{N}=\left(\mathrm{e}^{\gamma / \alpha}\right)^{3} \\
& \mathrm{P}=\mathrm{N}\left(\mathrm{e}^{\gamma / \alpha}\right)^{3}
\end{aligned}
$$

Introducing the value of $\mathrm{N}$ into equation (6)

$$
\mathrm{P}=4.25\left(\mathrm{e}^{\gamma / \alpha}\right)^{3}
$$

Where,

$$
\mathrm{P}=\text { Concentration of phosphorus removed during the leaching process }(\mathrm{mg} / \mathrm{Kg})
$$


$\mathrm{N}=4.25$; ( $\mathrm{pH}$ coefficient for phosphorus dissolution in sulphuric acid solution.) determined in the experiment[18].

$\alpha=$ Final $\mathrm{pH}$ of the leaching solution at the time $\mathrm{t}$ when the concentration of removed phosphorus is evaluated.

$\gamma=$ Initial $\mathrm{pH}$ of the leaching solution just before the leaching process started.

Equation (7) is the derived model.

Table1: Variation of initial and final $\mathrm{pH}$ of leaching solution with concentration of phosphorus removed.[18]

\begin{tabular}{|l|l|l|}
\hline$(\gamma)$ & $(\alpha)$ & $\mathrm{P}(\mathrm{mg} / \mathrm{Kg})$ \\
\hline 0.52 & 0.41 & 180.00 \\
0.48 & 0.39 & 214.00 \\
0.52 & 0.40 & 203.00 \\
0.48 & 0.41 & 199.75 \\
0.53 & 0.41 & 232.25 \\
0.50 & 0.40 & 198.00 \\
0.47 & 0.40 & 183.00 \\
\hline
\end{tabular}

Table2: Variation of $(\mathrm{P} / \mathrm{N})^{1 / 3}$ with $\left(\mathrm{e}^{\gamma / \alpha}\right)$

\begin{tabular}{|l|l|}
\hline$(\mathrm{P} / \mathrm{N})^{1 / 3}$ & $\left(\mathrm{e}^{\gamma / \alpha}\right)$ \\
\hline 3.4857 & 3.5548 \\
3.6927 & 3.4239 \\
3.6283 & 3.6693 \\
3.6088 & 3.2244 \\
3.7948 & 3.6425 \\
3.5983 & 3.4903 \\
3.5050 & 3.2381 \\
\hline
\end{tabular}




\section{BOUNDARY AND INITIAL CONDITION}

Iron oxide ore was placed in cylindrical flask $30 \mathrm{~cm}$ high containing leaching solution of sulphuric acid. The leaching solution is non flowing (stationary). Before the start of the leaching process, the flask was assumed to be initially free of attached bacteria and other micro organism. Initially, the effect of oxygen on the process was assumed to be atmospheric. In all cases, weight of iron oxide ore used; $2 \mathrm{~g}$. The initial $\mathrm{pH}$ range of leaching solutions used; $0.47-0.53$ and leaching time of $3 \mathrm{hrs}$ were used for all samples. A constant leaching temperature of $25^{\circ} \mathrm{C}$ was used. Sulphuric acid concentration at $0.1 \mathrm{~mol} / \mathrm{litre}$ and average ore grain size; $150 \mu \mathrm{m}$ were also used. Details of the experimental technique are as presented in the report [18].

The leaching process boundary conditions include: atmospheric levels of oxygen (considering that the cylinder was open at the top) at both the top and bottom of the ore particles in the gas and liquid phases respectively. A zero gradient was assumed for the liquid scalar at the bottom of the particles and for the gas phase at the top of the particles. The sides of the particles were assumed to be symmetries.

\section{MODEL VALIDATION}

The formulated model was validated by calculating the deviation of the model-predicted concentration of phosphorus removed from the corresponding experimental values. The deviation recorded is believed to be due to the fact that the surface properties of the ore and the physiochemical interactions between the ore and leaching solution which were found to play vital roles during the leaching process [18] were not considered during the model formulation. It is expected that introduction of correction factor to the predicted concentrations of $\mathrm{P}$, gives exactly the experimental values of $P$.

Deviation (Dv) (\%) of model- predicted $\mathrm{P}$ values from experimental $\mathrm{P}$ values is given by

$$
\begin{aligned}
& \text { Dv }=\left(\frac{P_{P}-P_{E}}{P_{E}}\right) \times 100 \\
& \text { Where } \quad P p=\text { Predicted } P \text { values } \\
& \\
& P_{E}=\text { Experimental } P \text { values }
\end{aligned}
$$


Since correction factor $(\mathrm{Cr})$ is the negative of the deviation,

$\mathrm{Cr}=-\mathrm{Dv}$

Substituting equation (8) into equation (9) for Dv,

$\mathrm{Cr}=-100\left(\frac{\mathrm{P}_{\mathrm{P}}-\mathrm{P}_{\mathrm{E}}}{\mathrm{P}_{\mathrm{E}}}\right)$

It was observed that addition of the corresponding values of $\mathrm{Cr}$ from equation (10) to the modelpredicted concentrations of $\mathrm{P}$ gave exactly the corresponding experimental $\mathrm{P}$ values. [18]

\section{RESULTS AND DISCUSSION}

The derived model is equation (7). Insignificant positive and negative deviations were found to have resulted on comparing values of $\mathrm{P}$ from the experimental data and those from the model, hence depicting the reliability and validity of the model. This can be deduced from Table 3 . The positive and negative deviations of the model-predicted $\mathrm{P}$ values from those of the experiment were found to be less than $29 \%$ which is quite within the acceptable deviation limit of experimental results. The validity of the model is believed to be rooted on equation (4) where both sides of the equation are almost equal. Table 2 also agrees with equation (4) following the values of $(\mathrm{P} / \mathrm{N})^{1 / 3}$ and $\left(\mathrm{e}^{\gamma / \alpha}\right)$ evaluated after statistical and computational analysis carried out on experimental results in Table1.

\section{CONCLUSION}

The model predicts the concentration of phosphorus removed (relative to the initial and final solution $\mathrm{pH}$ ) during leaching of Itakpe iron oxide ore. The validity of the model is believed to be rooted on equation (4) where both sides of the equation are almost equal. In all cases, the deviation of the model-predicted $\mathrm{P}$ value from that of the corresponding experimental $\mathrm{P}$ value is less than $29 \%$ which is quite within the acceptable deviation limit of experimental results. 
Table 3: Comparison between concentrations of phosphorus removed as predicted by model and as obtained from experiment [18].

\begin{tabular}{|l|l|l|l|}
\hline $\mathrm{P}_{\exp }(\mathrm{mg} / \mathrm{Kg})$ & $\mathrm{P}_{\mathrm{M}}(\mathrm{mg} / \mathrm{Kg})$ & $\mathrm{Dv}(\%)$ & $\mathrm{Cr}(\%)$ \\
\hline 180.00 & 190.91 & +6.06 & -6.06 \\
214.00 & 170.58 & -20.29 & +20.29 \\
203.00 & 209.96 & +3.43 & -3.43 \\
199.75 & 142.47 & -28.68 & +28.68 \\
232.25 & 205.40 & -11.56 & +11.56 \\
198.00 & 180.71 & -8.73 & +8.73 \\
183.00 & 144.30 & -21.15 & +21.15 \\
\hline
\end{tabular}

where $\mathrm{P}_{\exp }=\mathrm{P}$ values from experiment [18]

$\mathrm{P}_{\mathrm{M}}=\mathrm{P}$ values predicted by model.

\section{ACKNOWLEDGEMENT}

The authors thank Dr. Ekeme Udoh and Pearl Bassey, modelling experts at Linkwell Modelling Centre Calabar for his technical inputs. The management of SynchroWell Nig. Ltd. Enugu is also appreciated for permitting and providing the experimental data used in this work.

\section{REFERENCES}

[1] Lee, S. O., Oh, J. K., Shin, B. S., 1999, Dissolution of Iron Rust Materials using Oxalic Acid. J. Min. Metall. Inst. Jpn., Vol. 115, pp. 815-819.

[2] Taxiarchour, M., Panias, D., Doumi, I., Paspaliaris, I., Kontopoulos, A., (1997a) Removal of Iron from Silica Sand by Leaching with Oxalic Acid, Hydrometallurgy, 46, 215-227.

[3] Lee, S.O, Tran, T., Park Y.Y., Kim S.J., and Kim, M. J. (2006) Study on the Kinetics of Iron Leaching by Oxalic Acid.Int. J .Miner Process, 80, 144-152.

[4] Taxiarchou, M., Parnias, D., Doumi, I., Paspaliaris, I., and Kontopoulous, A. (1997b) Dissolution of Haematite in Acidic Oxalate Solutions. Hydrometallurgy, 44, 287-299. 
[5] Panias, D., Taxiarchou, M., Paspaliaris, I., Kontopoulos, A. (1996) Mechanism of Dissolution of Iron Oxides in Aqueous Oxalic Acid. Hydrometallurgy, 42, 257-265.

[6] Nwoye, C. I. (2008) Model for Quantitative Analysis of Dissolved Iron in Oxalic Acid Solution during Leaching of Iron Oxide Ore, Inter. Res. J. Eng. Sc. Tech., 5(1): 37-41.

[7] Nwoye, C. I., Amara, G. N., and Onyemaobi, O. O. (2008) Model for Evaluating Dissolved Iron during Leaching of Iron Oxide Ore in Sulphuric Acid Solution, Inter. J. Nat. Appl. Sc., 4(2): 209-211.

[8] Pinches, A. (1975) Bacterial Leaching of an Arsenic Bearing Sulphide Concentrate. The Institute of Mining and Metallurgy, England, 34.

[9] Nwoye, C. I. (2008) Ph.D Thesis, Metallurgical and Materials Engineering Department, Federal University of Technology,Owerri,178.

[10] Turkdogan, E.T., and Pearson, J., (1953) J. Iron and Steel Inst., 221, pp.393-401.

[11] Decker, A., Sevrin, R., and Scimar, R., (1962) Open Hearth Proceedings, 45, pp. 421- 456.

[12] Duke, D.A., Ramstad, H. F. and Meyer, H. W (1962) Open Hearth Proceedings, 45, pp.8198.

[13] Kootz,T., and Neuhaus, H., (1961) Stahl u. Eisen, 81, pp. 1810-1815.

[14] Kootz, K., Behrens, K., Maas, H., and Baumgarten, P. (1965) Stahl u. Eisen , 85, pp 857865.

[15] Edneral, F. P., (1979) Electrometallurgy of Steel and Ferro- alloys, MIR Publisher, 5th edition Moscow. pp 30-239.

[16] Zea,Y.K. (1945) J. Iron and Steel Inst., 151, pp. 459-504.

[17] Nwoye, C. I., Agu, P.C., Mark, U., Ikele, U.S., Mbuka, I. E., and Anyakwo, C. N. (2008) Model for Predicting Phosphorus Removal in Relation to Weight of Iron Oxide Ore and $\mathrm{pH}$ during Leaching with Oxalic Acid Inter. J. Nat. Appl. Sc., 4(3): 106-112.

[18] Nwoye, C. I. (2008) SynchroWell Research Work Report, DFM Unit, No 2000116, 36-50. 